\title{
Seismic Performance Comparison of a High-Content SDA Frame and Standard RC Frame
}

\author{
John W. van de Lindt ${ }^{1}$ and R. Karthik Rechan ${ }^{2}$ \\ ${ }^{1}$ Department of Civil, Construction, and Environmental Engineering, The University of Alabama, Tuscaloosa, AL 35487, USA \\ ${ }^{2}$ Department of Civil and Environmental Engineering, Colorado State University, Campus Delivery 1372, Fort Collins, \\ CO 80523-1372, USA
}

Correspondence should be addressed to John W. van de Lindt, jwvandelindt@eng.ua.edu

Received 3 November 2010; Accepted 24 June 2011

Academic Editor: J. Antonio H. Carraro

Copyright (๑) 2011 J. W. van de Lindt and R. K. Rechan. This is an open access article distributed under the Creative Commons Attribution License, which permits unrestricted use, distribution, and reproduction in any medium, provided the original work is properly cited.

\begin{abstract}
This study presents the method and results of an experiment to study the seismic behavior of a concrete portal frame with fifty percent of its cement content replaced with a spray dryer ash (SDA). Based on multiple-shake-table tests, the high content SDA frame was found to perform as well as the standard concrete frame for two earthquakes exceeding design-level intensity earthquakes. Hence, from a purely seismic/structural standpoint, it may be possible to replace approximately fifty percent of cement in a concrete mix with SDA for the construction of structural members in high seismic zones. This would help significantly redirect spray dryer ash away from landfills, thus, providing a sustainable greener alternative to concrete that uses only Portland cement, or only a small percentage of SDA or fly ash.
\end{abstract}

\section{Introduction}

Ash is a byproduct obtained during the combustion of coal. Fly ash is generally obtained from the chimneys of coal-fired power plants. Depending on the amount of calcium, silica, iron, and alumina content of the ash there are two classes of fly ash as defined by ASTM C618, specifically Class C and Class F fly ash. Class $\mathrm{C}$ fly ash has high-calcium content, and its carbon content is usually less than two percent, while Class F fly ash has a low-calcium content with a carbon content usually less than five percent. Fly Ash, due to its pozzolanic properties is often used as an additive to Portland cement in concrete production. The use of fly ash in concrete increases the strength and durability of the concrete and also decreases the heat of hydration and permeability of the concrete. The use of fly ash in concrete helps to reduce environmental pollution, because for every ton of fly ash used to replace Portland cement in the manufacture of concrete, there is a reduction of carbon dioxide emissions which is, for example, equal to the amount of carbon dioxide generated from the average automobile during a two-month period [1]. Since the majority of $\mathrm{SO}_{2}$ emissions into the atmosphere are due to coal fired power plants, many coal fired power plants in the United States are now utilizing spray dry absorbers for the reduction of these $\mathrm{SO}_{2}$ gas emissions. The result is SDA which has material and behavioral properties similar to fly ash, but a different chemical makeup. In this process alkali sorbents such as lime $(\mathrm{CaO})$ or calcium hydroxide $\left(\mathrm{Ca}(\mathrm{OH})_{2}\right)$ are mixed with water to form an aqueous slurry [2]. This slurry is sprayed into the flue gas in a cloud of fine droplets. $\mathrm{SO}_{2}$ is then captured with this sorbent and is dried by the heat of the flue gases. The dried mix of the sorbent and $\mathrm{SO}_{2}$ is collected. The ash utilized in the project described in this paper was from the Platte River Power Authority's Rawhide Power Plant (RPP) which uses the SDA system. The ash obtained from RPP power plant has a unit mass of $2.1 \mathrm{~g} / \mathrm{cc}$, and, due to its high sulphur content its chemical properties and mineralogical properties [3] are slightly different, and, therefore, it cannot be classified as Class C ash.

There have been numerous studies conducted on the use of ash in concrete. Swamy et al. [4] conducted tests 


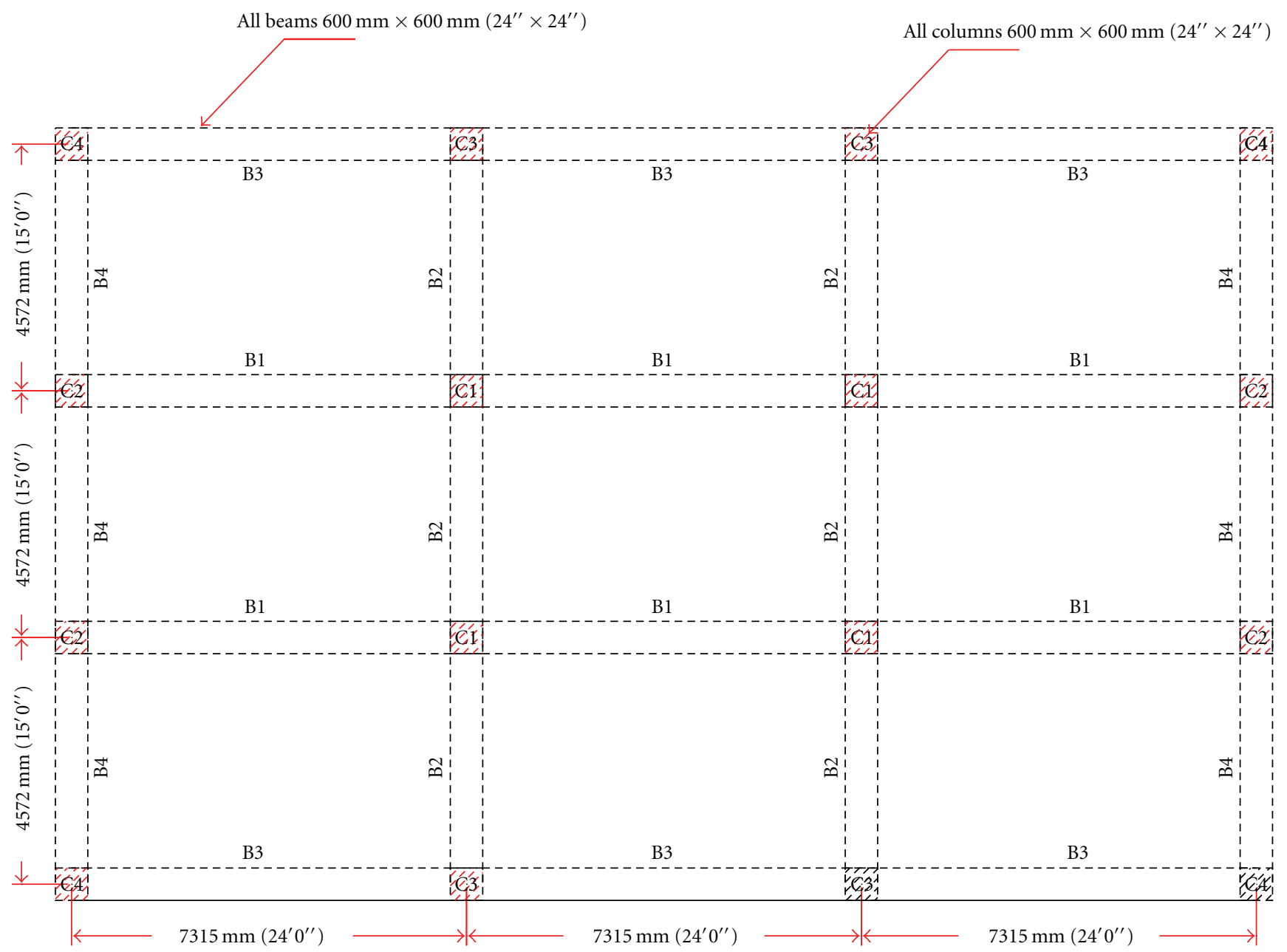

FIgURE 1: Plan of the prototype structure.

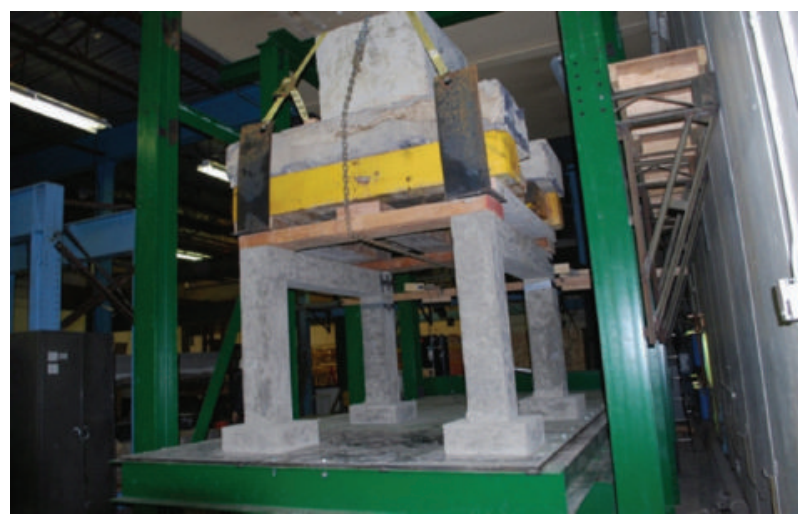

FIgURE 2: Experimental setup of the model on the shake table.

on reinforced concrete fly ash concrete beams and slabs containing normal weight aggregates and light weight aggregates. The results of their tests showed that concrete with fly ash can exhibit structural performance similar to that of conventional concrete with adequate safety factors used in existing design codes at the time. The results of their study also showed that structural concrete components can be designed to incorporate fly ash at quantities as high as 30 percent cement replacement, by weight.

Joshi et al. [5] studied the engineering properties of nonair-entrained concrete. Laboratory tests were conducted on both fly ash concrete and ordinary Portland cement concrete specimens. Based on properties such as compressive, flexural, indirect tensile strengths, and additional nondestructive tests, it was concluded that fly ash concrete could be used as a construction material for the core of a gravity dam and for pavement subbase. Hussain and Rasheeduzzafar [6] conducted accelerated corrosion tests on reinforced concrete specimens made of plain cement concrete and fly ash blended cement concrete. The results of the test showed superior corrosion resistance of fly ash concrete when compared to plain cement concrete. Pigeon and Malhotra [7] designed four high-volume fly ash-compacted concrete mixes by fixing 

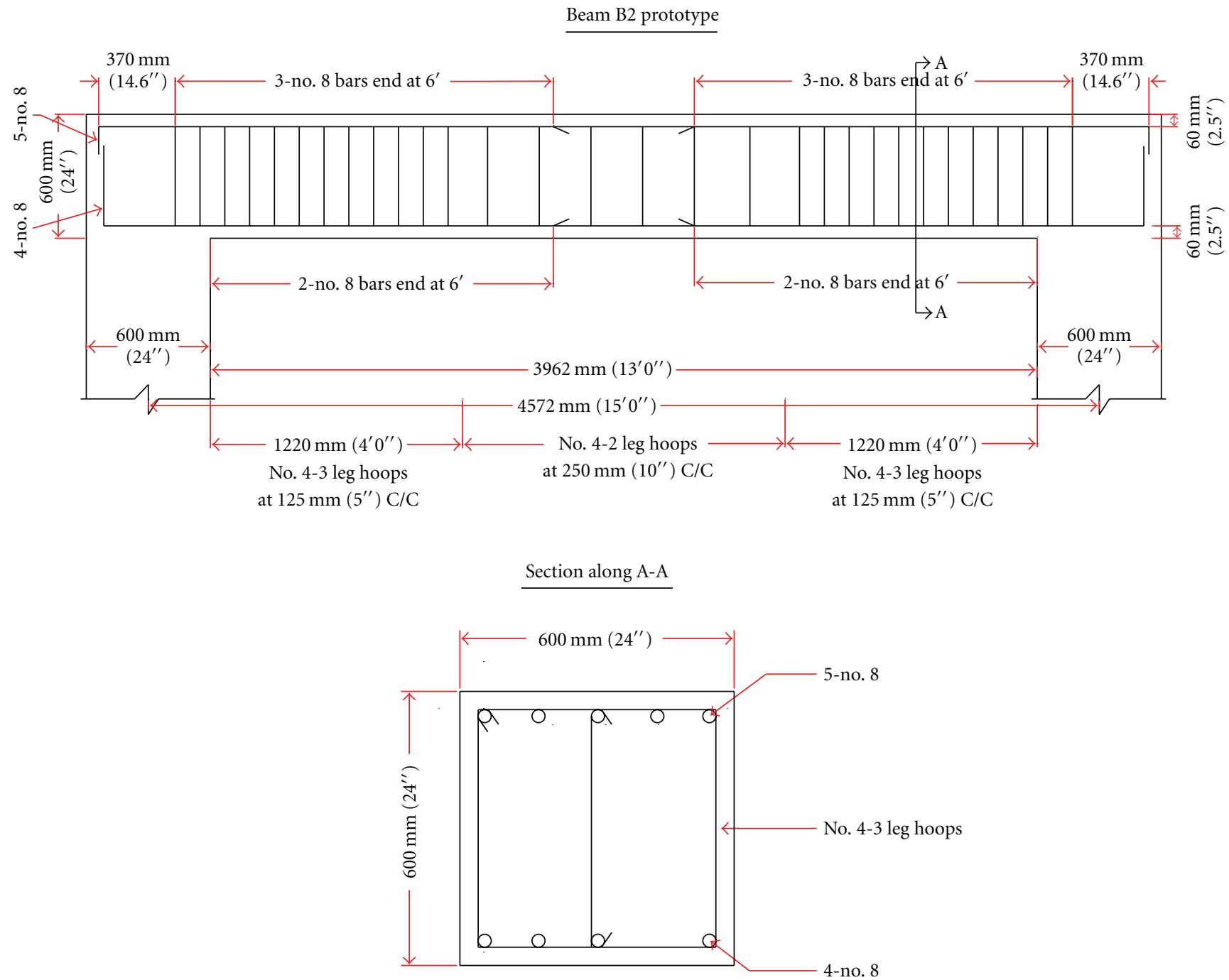

FIgURE 3: Reinforcement detail of prototype beam B2.

the amount of fly ash to the total cementitious material content. Laboratory investigations were carried out on airentrained and non-air-entrained concrete mixes, and the results showed that frost resistance of air-entrained concrete mixes was slightly more than that of non-air-entrained concrete mixes. The results of this study recommended the use of air entrainment for roller-compacted high-volume fly ash concretes.

Dinelli et al. [9] conducted experiments to find the possibility of partial or complete substitution of traditional aggregates in light weight concrete with aggregates made of fly ash. The results of their experiments demonstrated that traditional aggregate could be substituted with aggregate made of fly ash. Fernandez-Jimenez et al. [10] studied the durability of alkali-activated fly ash (AAFA) cement under different conditions and in a number of aggressive environments such as deionized water, ASTM sea water, sodium sulphate, and acidic solutions. Studies were also made with respect to alkali-silica reaction-induced expansion. Weight loss, compressive strength, variations in volume, presence of the products of degradation, and microstructural changes were the chief parameters which were studied. The results of the study showed that AAFA cement pastes performed satisfactorily in aggressive environments, and the degradation of the materials resulting from such processes was distinctly different from that of the ordinary Portland cement paste. The AAFA mortars were found to be compliant with the 16day expansion limit stipulated in ASTM standard C 1260-94 on potential alkali-silica reactivity.

Van de Lindt et al. [11] carried out a study to investigate the possibility of increasing the thermal efficiency of a light frame residential structure through the addition of fly ashscrap tire fiber composite to traditional fiberglass insulation in light-frame wood residential construction. They found that the fly ash-scrap tire composite not only provided a sustainable supplement to traditional insulation but also helped to significantly reduce the environmental issues associated with the disposal of these materials by diverting 
TABle 1: Details of beam B1.

\begin{tabular}{|c|c|c|c|c|c|c|c|}
\hline Case & Location & Sway direction & $\begin{array}{c}\mathrm{Mu}, \mathrm{KN}-\mathrm{m} \\
(\mathrm{k}-\mathrm{ft})\end{array}$ & Reinforcement provided & $\begin{array}{l}\text { As, } \mathrm{mm}^{2} \\
\left(\mathrm{in}^{2}\right)\end{array}$ & $\begin{array}{c}\text { pi Mn, KN-m } \\
(\mathrm{k}-\mathrm{ft})\end{array}$ & $\begin{array}{c}\mathrm{Mpr}, \mathrm{KN}-\mathrm{m} \\
(\mathrm{k}-\mathrm{ft})\end{array}$ \\
\hline 1 & $\begin{array}{c}\text { Exterior end } \\
\text { Negative moment }\end{array}$ & Left & $\begin{array}{l}-591.27 \\
(-436.1) \\
\end{array}$ & 7-No 8 & $\begin{array}{c}3,567.73 \\
(5.53) \\
\end{array}$ & $\begin{array}{c}-656.80 \\
(-484.43) \\
\end{array}$ & $\begin{array}{c}-888.41 \\
(-655.26) \\
\end{array}$ \\
\hline 2 & $\begin{array}{c}\text { Exterior end } \\
\text { Negative moment }\end{array}$ & Right & $\begin{array}{l}-591.27 \\
(-436.1) \\
\end{array}$ & 7-No 8 & $\begin{array}{c}3,567.73 \\
(5.53) \\
\end{array}$ & $\begin{array}{c}-656.80 \\
(-484.43) \\
\end{array}$ & $\begin{array}{c}-888.41 \\
(-655.26) \\
\end{array}$ \\
\hline 3 & $\begin{array}{c}\text { Exterior end } \\
\text { Positive moment }\end{array}$ & Right & $\begin{array}{c}295.64 \\
(218.05) \\
\end{array}$ & 4-No 8 & $\begin{array}{c}2,038.71 \\
(3.16)\end{array}$ & $\begin{array}{c}392.12 \\
(289.21) \\
\end{array}$ & $\begin{array}{c}536.82 \\
(395.94) \\
\end{array}$ \\
\hline 4 & $\begin{array}{c}\text { Exterior end } \\
\text { Positive moment }\end{array}$ & Left & $\begin{array}{c}295.64 \\
(218.05) \\
\end{array}$ & 4-No 8 & $\begin{array}{c}2,038.71 \\
(3.16) \\
\end{array}$ & $\begin{array}{c}392.12 \\
(289.21) \\
\end{array}$ & $\begin{array}{c}536.82 \\
(395.94) \\
\end{array}$ \\
\hline 5 & $\begin{array}{c}\text { Midspan } \\
\text { Positive moment }\end{array}$ & & $\begin{array}{c}147.81 \\
(109.02)\end{array}$ & 1-No 9 & & & \\
\hline
\end{tabular}

TABLe 2: Details of beam B2.

\begin{tabular}{|c|c|c|c|c|c|c|c|}
\hline Case & Location & Sway direction & $\begin{array}{l}\mathrm{Mu}, \mathrm{KN}-\mathrm{m} \\
(\mathrm{k}-\mathrm{ft})\end{array}$ & Reinforcement provided & $\begin{array}{l}\text { As, } \mathrm{mm}^{2} \\
\left(\mathrm{in}^{2}\right)\end{array}$ & $\begin{array}{c}\text { pi Mn, KN-m } \\
(\mathrm{k}-\mathrm{ft})\end{array}$ & $\begin{array}{c}\mathrm{Mpr}, \mathrm{KN}-\mathrm{m} \\
(\mathrm{k}-\mathrm{ft})\end{array}$ \\
\hline 1 & $\begin{array}{c}\text { Exterior end } \\
\text { Negative moment }\end{array}$ & Left & $\begin{array}{c}-448.02 \\
(-330.44) \\
\end{array}$ & 5 -No 8 & $\begin{array}{c}2,548.38 \\
(3.95) \\
\end{array}$ & $\begin{array}{l}-483.175 \\
(-356.35) \\
\end{array}$ & $\begin{array}{c}-658.93 \\
(-485.97) \\
\end{array}$ \\
\hline 2 & $\begin{array}{c}\text { Exterior end } \\
\text { Negative moment }\end{array}$ & Right & $\begin{array}{c}-448.02 \\
(-330.44) \\
\end{array}$ & $5-\mathrm{No} 8$ & $\begin{array}{c}2,548.38 \\
(3.95) \\
\end{array}$ & $\begin{array}{l}-483.175 \\
(-356.35) \\
\end{array}$ & $\begin{array}{c}-658.93 \\
(-485.97) \\
\end{array}$ \\
\hline 3 & $\begin{array}{c}\text { Exterior end } \\
\text { Positive moment }\end{array}$ & Right & $\begin{array}{c}295.64 \\
(218.05) \\
\end{array}$ & 4 -No 8 & $\begin{array}{c}2,038.71 \\
(3.16) \\
\end{array}$ & $\begin{array}{c}323.23 \\
(238.38) \\
\end{array}$ & $\begin{array}{c}443.75 \\
(327.27) \\
\end{array}$ \\
\hline 4 & $\begin{array}{c}\text { Exterior end } \\
\text { Positive moment }\end{array}$ & Left & $\begin{array}{c}295.64 \\
(218.05) \\
\end{array}$ & 4 -No 8 & $\begin{array}{c}2,038.71 \\
(3.16)\end{array}$ & $\begin{array}{c}323.23 \\
(238.38) \\
\end{array}$ & $\begin{array}{c}443.75 \\
(327.27) \\
\end{array}$ \\
\hline 5 & $\begin{array}{c}\text { Midspan } \\
\text { Positive moment }\end{array}$ & & $\begin{array}{c}83.91 \\
(61.89)\end{array}$ & 2-No 8 & & & \\
\hline
\end{tabular}

TABLE 3: Scale factors used for modeling.

\begin{tabular}{|c|c|c|c|}
\hline \multirow{2}{*}{ Quantity } & \multirow{2}{*}{ General case } & \multicolumn{2}{|c|}{ Same material and acceleration (Model) } \\
\hline & & Required & Provided \\
\hline Geometric length, $l$ & $S_{l}=3.0$ & $S_{l}=3.0$ & $S_{l}=3.0$ \\
\hline Elastic modulus, $E$ & $S_{E}=1.0$ & $S_{E}=1.0$ & $S_{E}=1.0$ \\
\hline Acceleration, $a$ & $S_{a}=\left(=1 / S_{l} * S_{E} / S_{\rho}\right)$ & $S_{a}=1.0$ & $S_{a}=1.0$ \\
\hline Density, $\rho$ & $S_{\rho}=S_{E} /\left(S_{l} S_{a}\right)$ & $S_{\rho}=.33$ & $S_{\rho}=1.0$ \\
\hline Velocity, $v$ & $S_{v}=\sqrt{\left(S_{l} S_{a}\right)}$ & $S_{v}=1.73$ & $S_{v}=1.73$ \\
\hline Forces, $f$ & $S_{f}=S_{E} S_{l}^{2}$ & $S_{f}=9.0$ & $S_{f}=9.0$ \\
\hline Stress, $\sigma$ & $S_{\sigma}=S_{E}$ & $S_{\sigma}=1.0$ & $S_{\sigma}=1.0$ \\
\hline Strain, $\varepsilon$ & $S_{\varepsilon}=1.0$ & $S_{\varepsilon}=1.0$ & $S_{\varepsilon}=1.0$ \\
\hline Area, $A$ & $S_{A}=S_{l}^{2}$ & $S_{A}=9.0$ & $S_{A}=9.0$ \\
\hline Volume, $V$ & $S_{V}=S_{l}^{3}$ & $S_{V}=27$ & $S_{V}=27.0$ \\
\hline Second moment of area, $I$ & $S_{I}=S_{l}^{4}$ & $S_{I}=81$ & $S_{I}=81.0$ \\
\hline Mass, $m$ & $S_{m}=S_{\rho} S_{l}^{3}$ & $S_{m}=9$ & $S_{m}=27$ \\
\hline Impulse, $i$ & $S_{i}=S_{l}^{3} \sqrt{\left(S_{\rho} S_{E}\right)}$ & $S_{i}=15.59$ & $S_{i}=27$ \\
\hline Energy, $e$ & $S_{e}=S_{e} S_{l}^{3}$ & $S_{e}=27.0$ & $S_{e}=27.0$ \\
\hline Frequency, $\omega$ & $S_{\omega}=1 / S_{s} \sqrt{\left(S_{E} / S_{\rho}\right)}$ & $S_{\omega}=0.58$ & $S_{\omega}=0.33$ \\
\hline Time (Period), $t$ & $S_{t}=\sqrt{S_{l} / S_{a}}$ & $S_{t}=1.73$ & $S_{t}=1.73$ \\
\hline Gravitational acceleration, $g$ & $S_{g}=1.0$ & $S_{g}=1.0$ & $S_{g}=1.0$ \\
\hline Gravitational force, fg & $S_{\mathrm{fg}}=S_{\rho} S_{l}^{3}$ & $S_{\mathrm{fg}}=9.0$ & $S_{\mathrm{fg}}=27.0$ \\
\hline Critical damping, $\xi$ & $S_{\xi}=1.0$ & $S_{\xi}=1.0$ & $S_{\xi}=1.0$ \\
\hline
\end{tabular}

All the scale factors are obtained from [8]. 


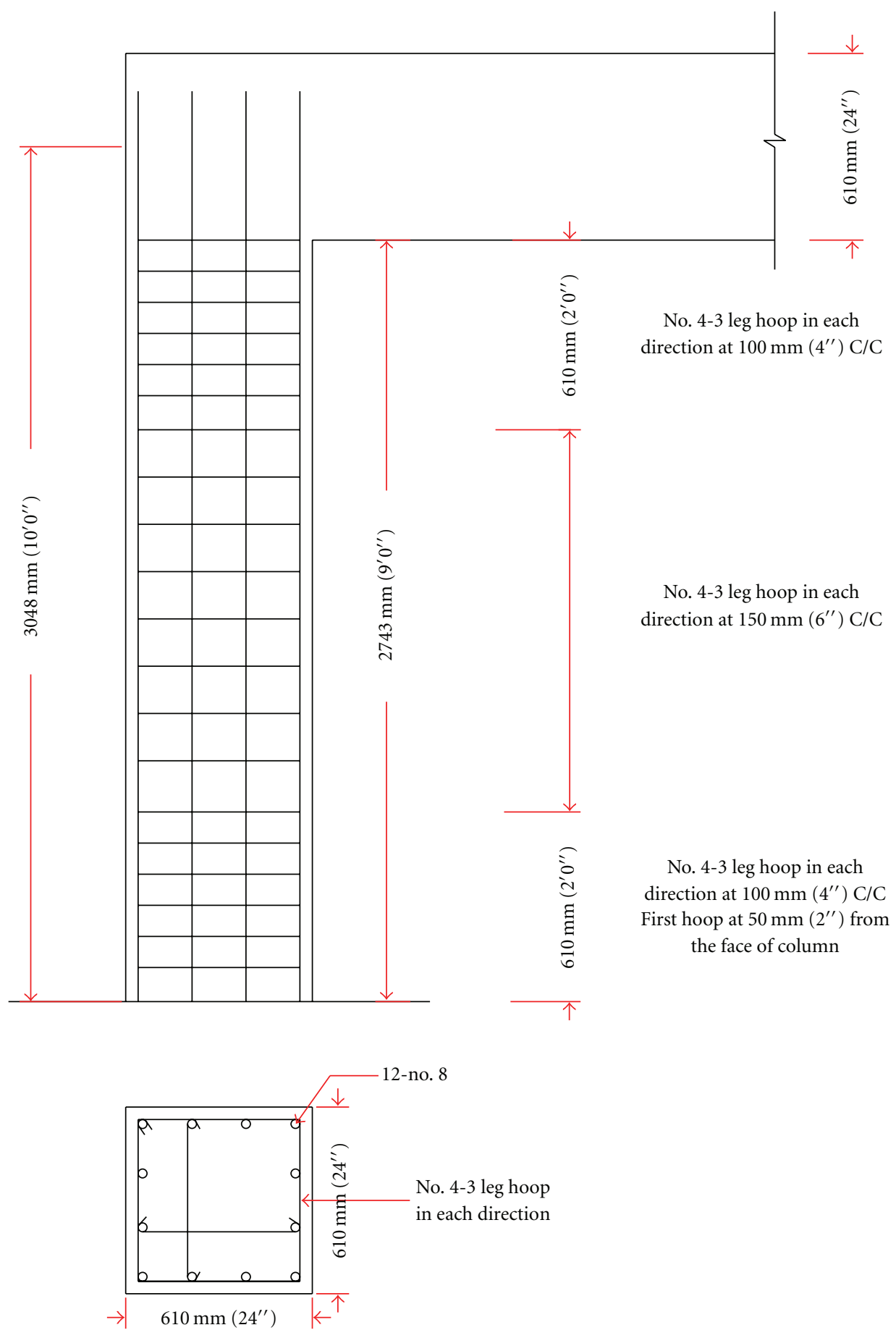

FIgURE 4: Reinforcement detail of the prototype column.

them from a landfill. Other numerous studies have been conducted over the past decades with most of them focusing on fly ash concrete and its use as a concrete additive.

The objective of this study was to evaluate the seismic behavior of concrete portal frames when replacing fifty percent of their cement content with spray dryer ash (SDA) and comparing that with the seismic behavior of ordinary Portland cement concrete frames when subjected to the same ground motions. Figure 1 shows the plan view of the three storey office building that served as the example building for this study. The building was designed for seismic load conditions per ASCE 7-05 [12] and seismic detailing according to ACI 318-05 [13] as if it were situated in Los Angeles, California. A mid bay portal frame was selected as the prototype frame, and, in total, four similar $1 / 3$ scale models of this frame were constructed for testing. Two 
Plan of model

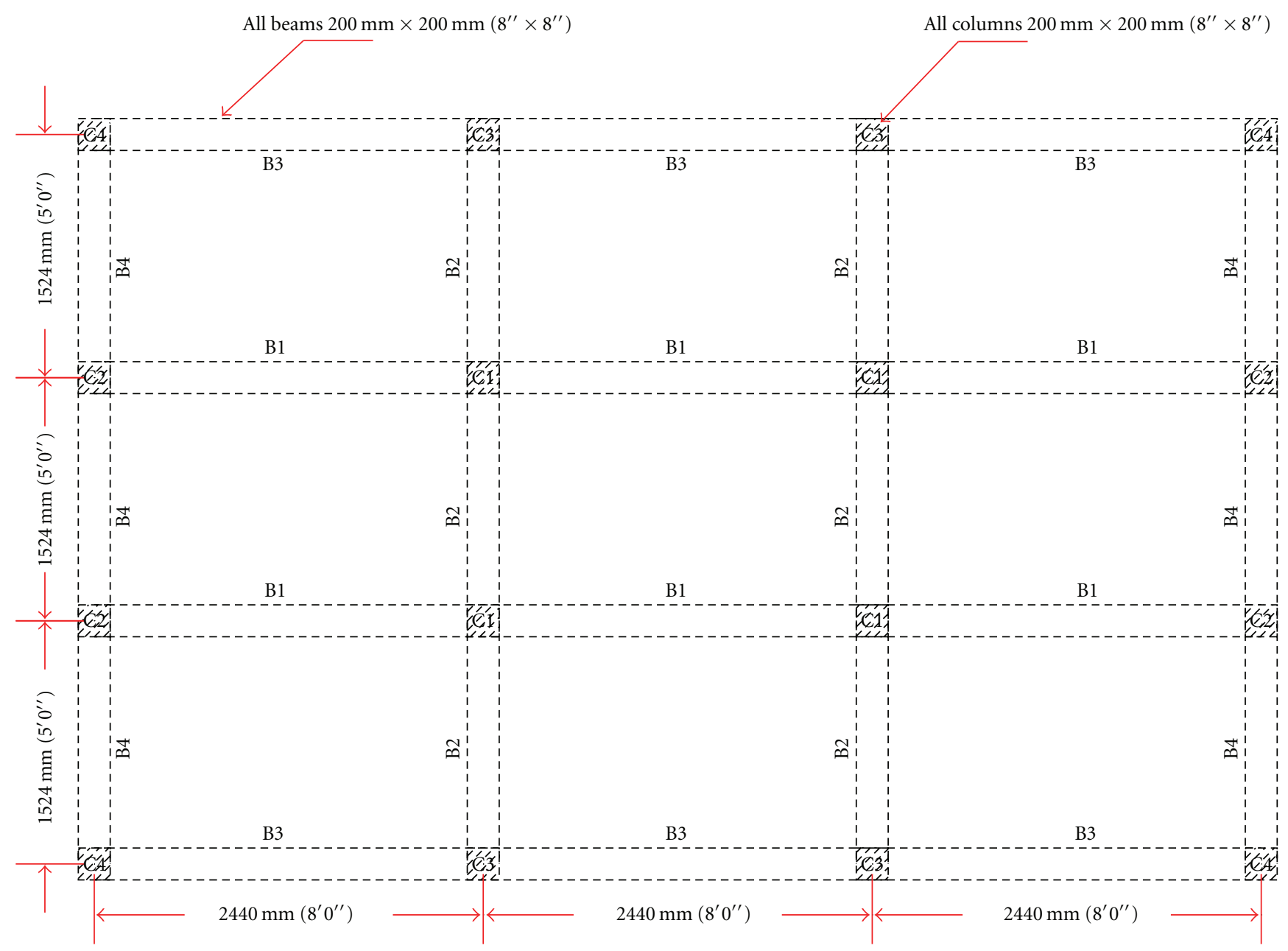

FIGURE 5: Plan of the 1/3rd scaled model.

TABLE 4: SDA concrete mix Design weights for 0.093 cubic meter ( 1 cubic foot) of $50 \%$ SDA concrete.

\begin{tabular}{lc}
\hline Type II Portland cement & $5.07 \mathrm{~kg}(11.17 \mathrm{lb})$ \\
Spray dryer ash & $5.07 \mathrm{~kg}(11.17 \mathrm{lb})$ \\
Sand & $24.21 \mathrm{~kg}(53.38 \mathrm{lb})$ \\
$19 \mathrm{~mm}\left(3 / 4^{\prime \prime}\right.$ coarse aggregate $)$ & $32.49 \mathrm{~kg}(71.62 \mathrm{lb})$ \\
Water & $3.38 \mathrm{~kg}(7.46 \mathrm{lb})$ \\
High-range water reducer & $3.3 \mathrm{~mL}$ \\
W/CM ratio & 0.33 \\
Compressive strength & $\mathrm{MPa}(\mathrm{psi})$ \\
7 days & $20.04(2907)$ \\
21 days & $37.79(5482)$ \\
28 days & $46.91(6803)$ \\
\hline
\end{tabular}

frames were constructed with fifty percent SDA concrete and the other two frames were constructed with ordinary Portland cement concrete.
TABle 5: Type II Portland cement concrete mix design weights for 0.093 cubic meter (1 cubic foot) of concrete.

\begin{tabular}{lc}
\hline & $\mathrm{kg}(\mathrm{lb})$ \\
\hline Water & $6.44(14.19)$ \\
Cement & $14.94(32.93)$ \\
$19 \mathrm{~mm}\left(3 / 4^{\prime \prime}\right)$ coarse aggregate & $22.68(50.00)$ \\
Fine aggregate & $90.72(200)$ \\
\hline
\end{tabular}

\section{Design and Construction}

2.1. Frame Design. The frame tested on the shake table was selected from the center bay of a three story office building having three bays in both the $X$ and $Y$ directions as shown in Figure 1. The office building was selected such that there were no plan irregularities or vertical irregularities. A $200 \mathrm{~mm}$ (8 inch) thick reinforced concrete slab was assumed for the load calculations on beams. Design loads and load factors were selected as per the seismic load combinations from ASCE 7-05 [12]. The prototype frames were selected for 

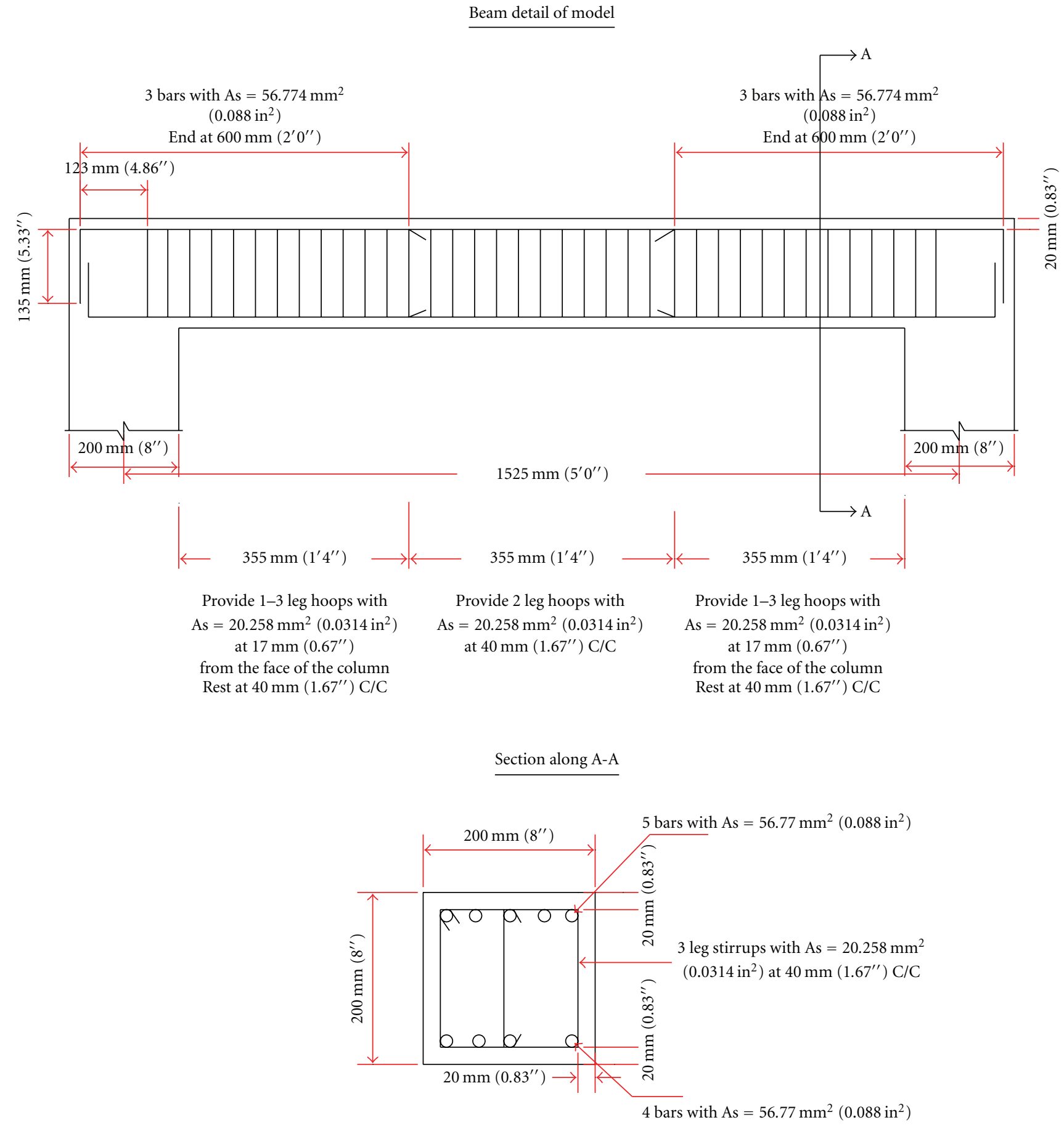

FIGURE 6: Reinforcement details of the 1/3rd scaled beam B2.

the design such that two $1 / 3$ scaled frames were able to be placed parallel to each other and tested on the shake table. The frames were designed as reinforced concrete special moment frames (SMF) for seismic resistance as per seismic detailing provisions of ACI 318-05 [13]. The material strengths assumed for the design were ASTM Grade 60 steel, $f_{y}=414 \mathrm{MPa}(60 \mathrm{ksi})$, and ordinary type II Portland cement concrete having a 28 -day compressive strength of $27.6 \mathrm{MPa}$ (4000 psi).
2.2. Beam Design. The beams were designed as the flexural members of special moment-resisting frames (SMRFs) according to special provisions for seismic design from chapter 21 of the American Concrete Institute code. The maximum design loads for the analysis of the frame were determined from the above load combinations and the storey shear was applied to each storey. The design shear forces are based on the factored dead loads, live loads, plus the shear due to hinging at the ends of the beams for the frames 


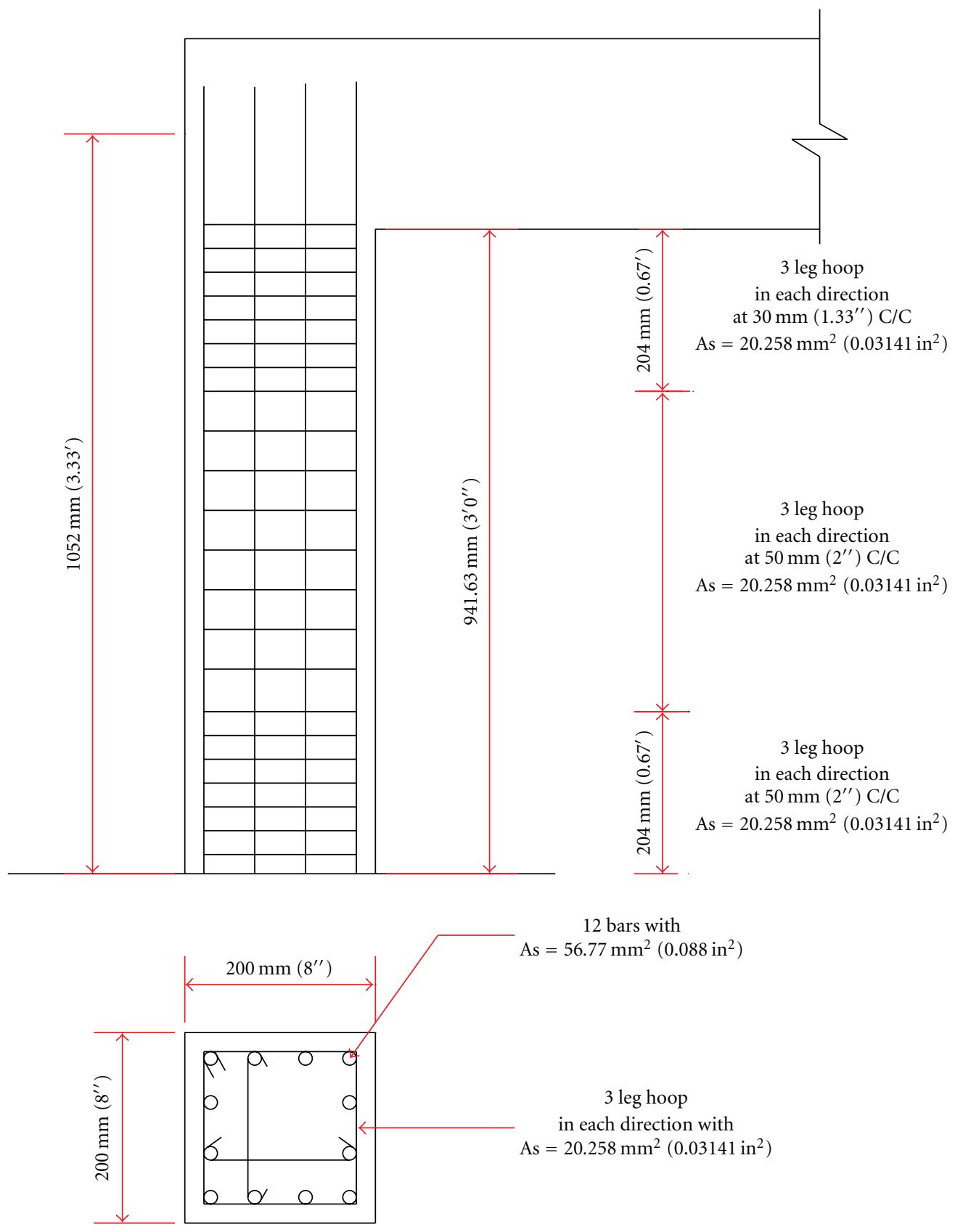

Figure 7: Reinforcement detail of the 1/3rd scaled column.

TABLE 6: Ground motion details of earthquakes used to excite the structure.

\begin{tabular}{lccc}
\hline Earthquake event \& year & File name & Station & Peak ground acceleration $(\mathrm{g})$ \\
\hline Northridge (1994) & Nor5 & LA-Hollywood Storage & 0.778 \\
Landers (1992) & Lan1 & Desert Hot Springs & 0.875 \\
\hline
\end{tabular}

swaying either to the left or to the right. Beams having cross-section $(\mathrm{c} / \mathrm{s}) 609.6 \mathrm{~mm} \times 609.6 \mathrm{~mm}\left(24^{\prime \prime} \times 24^{\prime \prime}\right)$ were designed according to section 21.3 of the ACI code. The ultimate moment, $M_{\mathrm{u}}$, reinforcement selected for the beam c/s, nominal moment, $\varphi M_{\mathrm{n}}$, and the probable moment, $M_{\mathrm{pr}}$, used in the design of the beams B1 and B2 are shown in Tables 1 and 2. The interested reader is referred to ACI 31805 code for a detailed procedure of beam design for a SMRF. Figure 3 presents the resulting detailing of the reinforcement for the beams. 


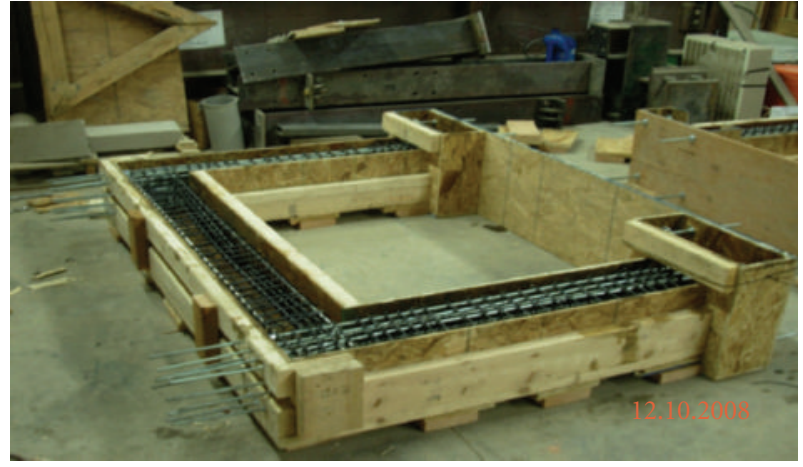

FIGURE 8: Formwork before pouring of concrete.

TABLE 7: Test sequence.

\begin{tabular}{lcc}
\hline Test sequence & Ground motions & Peak ground acceleration $(\mathrm{g})$ \\
\hline 1 & Lan1 & 0.875 \\
2 & Nor5 & 0.778 \\
3 & Nor5 & 0.778 \\
4 & Nor5 & 0.778 \\
5 & Nor5 & 0.973 \\
\hline
\end{tabular}

2.3. Column Design. The Columns were designed as per ACI section 21.4.2 using the strong column weak beam concept. This type of design care is taken to ensure that plastic hinges first form in the beams and not in the columns; hence the risk of lateral instability (leading to collapse) is minimized. The prototype column had a cross-section $608 \mathrm{~mm} \times 608 \mathrm{~mm}\left(24^{\prime \prime} \times 24^{\prime \prime}\right)$ with 12 -\#8 bars; however, the interaction diagram is not presented here for brevity. From the interaction diagram, $\sum M_{\mathrm{nc}}$ was found to be $1,721.89 \mathrm{kN}$ $\mathrm{m}$ (1270 kip-ft) which is greater than $6 / 5$ the value of $\sum M_{\mathrm{nb}}$ which was found to be $967.62 \mathrm{kN}-\mathrm{m}$ (713.676 kip-ft) when no. 4 bars with 3 leg hoops in each direction are provided as per the requirements of the ACI code to resist shear and for the confinement of longitudinal bars in the column. The beam column joint was designed as per section 21.5 of the $\mathrm{ACI}$ code. The detailing of the prototype column is shown in Figure 4.

2.4. Model Scaling Law. The model was scaled by using the Buckingham pi theorem [14]. The Buckingham pi theorem states that any dimensionally homogenous equation involving certain physical quantities can be reduced to an equivalent equation involving a complete set of dimensionless products. Figure 5 shows the plan view for the one-third scale model of the prototype. Design and properties of one third scale model structures have been tested successfully before (see, e.g., [8]). The length factor used for scaling is 3 and Table 3 shows the scale factors for other quantities. The reinforcement bars provided for the prototype beams and columns to resist flexure and shear are no. 8 and no. 4 bars having yield strength of $413.68 \mathrm{MPa}(60 \mathrm{ksi})$. The cross-sectional areas of no. 8 and no. 4 grade 60 bars are $509.68 \mathrm{~mm}^{2}\left(0.79 \mathrm{in}^{2}\right)$ and $129.03 \mathrm{~mm}^{2}\left(0.2 \mathrm{in}^{2}\right)$,

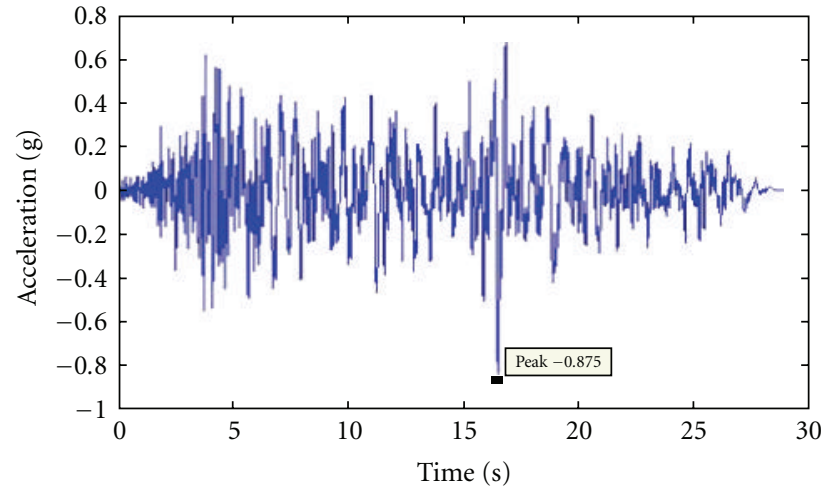

FIgURE 9: Time-compressed acceleration record for the 1992 Landers earthquake.

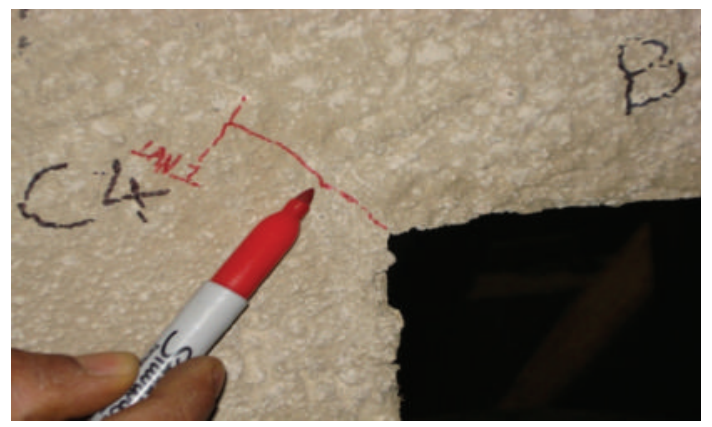

FIGURE 10: Shear crack in the column of the SDA concrete frame after test sequence 1 .

respectively. Hence, by referring to Table 3 , one can see that a yield force scale factor of 9 is used to find the required area of the reinforcing steel in the model. Thus, bars having areas of $56.8 \mathrm{~mm}^{2}\left(0.088 \mathrm{in}^{2}\right)$ and $14.2 \mathrm{~mm}^{2}\left(0.022 \mathrm{in}^{2}\right)$ must be provided for reinforcement in the model. Threaded steel bar having a diameter of $9.52 \mathrm{~mm}\left(3 / 8^{\prime \prime}\right)$, that is, and crosssectional area of $71 \mathrm{~mm}^{2}\left(0.11 \mathrm{in}^{2}\right)$ was used, and $5.08 \mathrm{~mm}$ $\left(0.2^{\prime \prime}\right)$ diameter galvanized steel wires having cross-area of $20.3 \mathrm{~mm}^{2}\left(0.0314 \mathrm{in}^{2}\right)$ were used as flexural and shear reinforcement in model, respectively. All-thread rods were used instead of no. 3 rebar as the effective area excluding threads is less than that of no. 3 rebar and close to the required area of $56.8 \mathrm{~mm}^{2}\left(0.088 \mathrm{in}^{2}\right)$. Figures 6 and 7 show the reinforcement details of the model.

2.5. Mix Designs. The material properties and compressive strength of the model and the prototype are considered to be the same; hence, the scale factor of one is considered for the mix design since the acceleration and the materials of the model and the prototype are the same, as can be seen in Table 3.

The mix design for the spray dryer ash (SDA) concrete mix was obtained from the study by King [15]. A few modifications were made to the mix design, specifically that SDA was used instead of Class F fly ash as mentioned in the original mix design. Fifty percent of cement and fifty percent of SDA were used for the mix instead of $45 \%$ of cement and 
TABle 8: Damage assessment of Portland cement concrete frame.

\begin{tabular}{|c|c|c|c|c|c|c|}
\hline \multirow{3}{*}{$\begin{array}{l}\text { Test } \\
\text { sequence }\end{array}$} & \multicolumn{6}{|c|}{ Portland cement concrete frame } \\
\hline & \multicolumn{3}{|c|}{ Columns } & \multicolumn{3}{|c|}{ Beams } \\
\hline & $\mathrm{C} 1$ & $\mathrm{C} 2$ & $\mathrm{C} 3$ & $\mathrm{C} 4$ & $\mathrm{~B} 1$ & $\mathrm{~B} 1$ \\
\hline 1 & - & - & - & - & - & - \\
\hline 2 & - & $\begin{array}{l}\text { Shear crack at the } \\
\text { outer face of the } \\
\text { beam-column joint }\end{array}$ & $\begin{array}{l}\text { Shear crack at both } \\
\text { inner and outer faces } \\
\text { of the beam-column } \\
\text { joints }\end{array}$ & $\begin{array}{l}\text { Shear crack at the } \\
\text { inner face of the } \\
\text { beam-column joint }\end{array}$ & - & - \\
\hline 3 & $\begin{array}{l}\text { Shear crack at the } \\
\text { outer face of the } \\
\text { beam-column joint }\end{array}$ & $\begin{array}{l}\text { Vertical crack } \\
\text { extension towards the } \\
\text { end of outer face of } \\
\text { the column }\end{array}$ & $\begin{array}{l}\text { Vertical crack } \\
\text { extending till the end } \\
\text { of the outer face of } \\
\text { the column }\end{array}$ & - & - & $\begin{array}{l}\text { Vertical crack at the } \\
\text { end of the beam near } \\
\text { column C3 }\end{array}$ \\
\hline 4 & $\begin{array}{l}\text { Vertical crack on the } \\
\text { outer face of the } \\
\text { column }\end{array}$ & - & - & $\begin{array}{l}\text { Shear crack at the } \\
\text { outer face of the } \\
\text { beam-column joint }\end{array}$ & - & - \\
\hline 5 & - & - & - & - & - & - \\
\hline
\end{tabular}

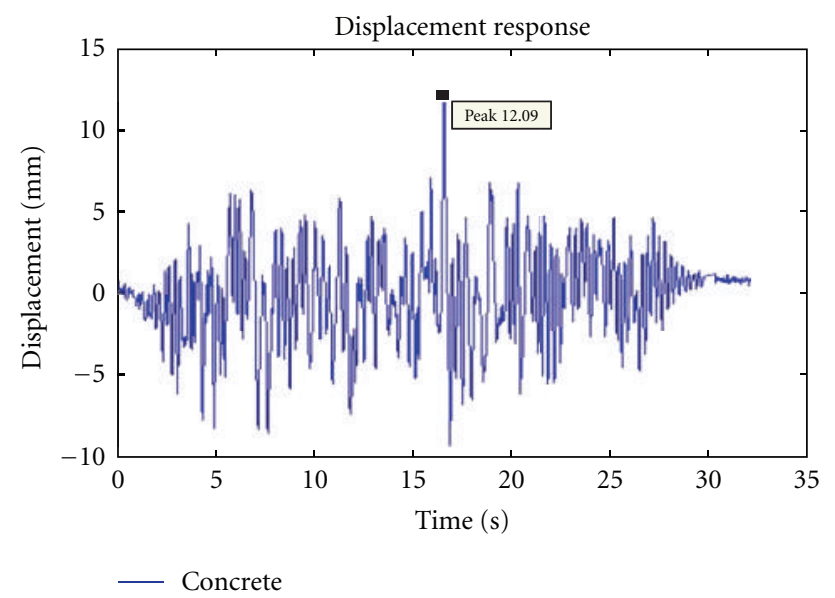

FIGURE 11: Displacement response of concrete frame, column after test sequence 1 .

$55 \%$ of fly ash as mentioned in their original mix design. Only $19 \mathrm{~mm}\left(3 / 4^{\prime \prime}\right)$ diameter coarse aggregate was used since the model was $1 / 3$ scale, and high-range water reducers were used as mentioned in the mix design. The mix design and the obtained compressive strengths of the SDA concrete are shown in Table 4 and this mix designs for Portland Cement Concrete is shown in Table 5.

Both mix designs targeted a 28-day compressive strength of $31.03 \mathrm{MPa}$ (4500 psi). Both mix designs resulted in compressive strengths exceeding the desired compressive strength but were felt to be reasonable to achieve comparative results and to assess whether a 50\% SDA content mix could be used in seismic design. Qualitatively, this difference was accounted for in the performance comparison in the conclusions.

\section{Experimental Setup}

A $4.57 \mathrm{~m}\left(15^{\prime}\right)$ long $1 / 3$ scale portal frame from the center bay of the plan (see Figure 5) was selected for design, construction, and testing. Four portal frames were constructed in total for the experiment. Specifically, two frames were made of ordinary Portland cement concrete having a compressive strength of $56.33 \mathrm{MPa}(8170 \mathrm{psi})$, and two frames were made of concrete in which $50 \%$ of the cement was replaced with SDA, having a compressive strength of $46.91 \mathrm{MPa}$ (6803 psi). Figure 8 shows the setup of the formwork just prior to pouring. The column bars were extended about $150 \mathrm{~mm}$ ( 6 inches) out of the formwork so that the two frames could be tied together while testing thus restricting them from out of plane motion. The SDA concrete was poured, and then plain cement concrete was poured into the remaining formwork one day apart. The concrete was allowed to cure for 28 days, and the models were deemed ready for testing. The seismic mass was calculated using a mass similitude factor of 9 , by referring to Table 3 and by using the mass similitude procedure outlined in Bracci et al. [8]. The seismic mass to be placed on the model was found to be $8000 \mathrm{~kg}$ $(17600 \mathrm{lb})$. Figure 2 shows the setup of models with the seismic mass on the shake table just prior to testing. Three displacement gauges were used to measure the displacement of the frames, one at the neutral axis of each beam and one for shake table displacement.

\section{Seismic Test Program}

The portal frames were both tested on the uniaxial shake table at Colorado State University using a total of five different earthquakes in succession. The Canoga Park recording of the 1994 Northridge, California earthquake (recorded at a site known as the Hollywood storage facility) and 1992 Landers earthquake were selected as input ground motions. Table 6 provides the peak ground motion details for the scaling of the records used to excite the structure, and Table 7 shows the name, peak ground acceleration, and the test sequence of the earthquakes used in the test of each specimen. Figure 9 shows the time-compressed acceleration response for the 1992 Landers earthquake. The 1994 Northridge earthquake record is not shown here for brevity. Referring to Table 3 , one can see that the time 
TABLE 9: Damage assessment of SDA concrete frame.

\begin{tabular}{|c|c|c|c|c|c|c|}
\hline \multirow{3}{*}{ Test sequence } & \multicolumn{6}{|c|}{ SDA concrete frame } \\
\hline & \multicolumn{3}{|c|}{ Columns } & \multicolumn{3}{|c|}{ Beams } \\
\hline & $\mathrm{C} 1$ & $\mathrm{C} 2$ & $\mathrm{C} 3$ & $\mathrm{C} 4$ & B1 & B2 \\
\hline 1 & $\begin{array}{l}\text { A thick crack at the outer } \\
\text { face of the column edge }\end{array}$ & - & - & $\begin{array}{l}\text { Shear crack at the inner } \\
\text { face of the beam-column } \\
\text { joint }\end{array}$ & - & - \\
\hline 2 & - & - & $\begin{array}{l}2 \text { Vertical cracks on the } \\
\text { outer face of the column }\end{array}$ & $\begin{array}{l}\text { Vertical crack on the outer } \\
\text { face of the column }\end{array}$ & - & - \\
\hline 3 & $\begin{array}{l}\text { Diagonal crack at the } \\
\text { outer face of the column }\end{array}$ & - & $\begin{array}{l}\text { Vertical crack on the outer } \\
\text { face of column }\end{array}$ & - & - & - \\
\hline 4 & 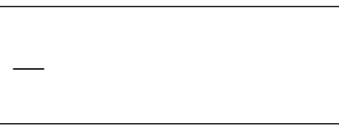 & - & $\begin{array}{l}\text { Shear crack at the inner } \\
\text { face of the beam-column } \\
\text { joint }\end{array}$ & $\begin{array}{l}\text { Shear crack at the inner } \\
\text { face of the beam-column } \\
\text { joint }\end{array}$ & - & $\begin{array}{l}\text { Vertical crack on the } \\
\text { inner face of the beam } \\
\text { near column C4 }\end{array}$ \\
\hline 5 & - & - & $\begin{array}{l}\text { (a) Horizontal crack } \\
\text { exactly below the } \\
\text { beam-column joint of } \\
\text { column C3 and beam B2 } \\
\text { (b) Vertical crack at mid } \\
\text { height on outer face of the } \\
\text { column }\end{array}$ & $\begin{array}{l}\text { (a) Extended vertical } \\
\text { crack on the outer face of } \\
\text { the column } \\
\text { (b) Base of the column } \\
\text { damaged } \\
\text { (c) Vertical crack at the } \\
\text { mid height of the column } \\
\text { (d) Horizontal crack } \\
\text { exactly below the beam } \\
\text { column joint of the } \\
\text { column and beam B2 }\end{array}$ & - & - \\
\hline
\end{tabular}

TABLE 10: Peak displacement response values of concrete and SDA concrete frames.

\begin{tabular}{|c|c|c|c|c|}
\hline \multirow{3}{*}{$\begin{array}{l}\text { Test } \\
\text { sequence }\end{array}$} & \multicolumn{4}{|c|}{ Peak displacement response values } \\
\hline & Concret & e frames & SDA concr & ete frames \\
\hline & $\begin{array}{c}\text { Column C2, } \\
\mathrm{mm}\end{array}$ & $\begin{array}{c}\text { Column C3, } \\
\mathrm{mm}\end{array}$ & $\begin{array}{c}\text { Column C2, } \\
\mathrm{mm}\end{array}$ & $\begin{array}{c}\text { ColumnC3, } \\
\mathrm{mm}\end{array}$ \\
\hline 1 & 12.09 & 11.24 & 13.85 & 8.44 \\
\hline 2 & 11.94 & 10.6 & 11.46 & 9.77 \\
\hline 3 & 9.99 & 10.46 & 12.89 & 11.87 \\
\hline 4 & 11.24 & 10.4 & 14 & 9.88 \\
\hline 5 & 13.74 & 13.46 & 12.9 & 11.53 \\
\hline
\end{tabular}

was scaled by a square root of the length factor. Since the scale factor for acceleration is unity, input acceleration values remain unchanged and time is simply compressed by $1 /$ sqrt(3).

The concrete and SDA frame models were tested on the shake table in the sequence shown in Table 7. Tables 8 and 9 provide a summary of the damage assessment after each test sequence for the Portland cement concrete and SDA concrete frames, respectively.

Referring to the peak responses in Table 10, the peak displacement values of column C3 and Column C2 after test sequence 1 for the Portland cement concrete frame were approximately equal to the peak displacements of Column $\mathrm{C} 3$ and Column C2 in the SDA concrete frame. Figure 10 shows a typical shear crack observed in the SDA frame columns after the test sequence. Figures 11 and 12 present the time history of the displacement response for Test 1 at the

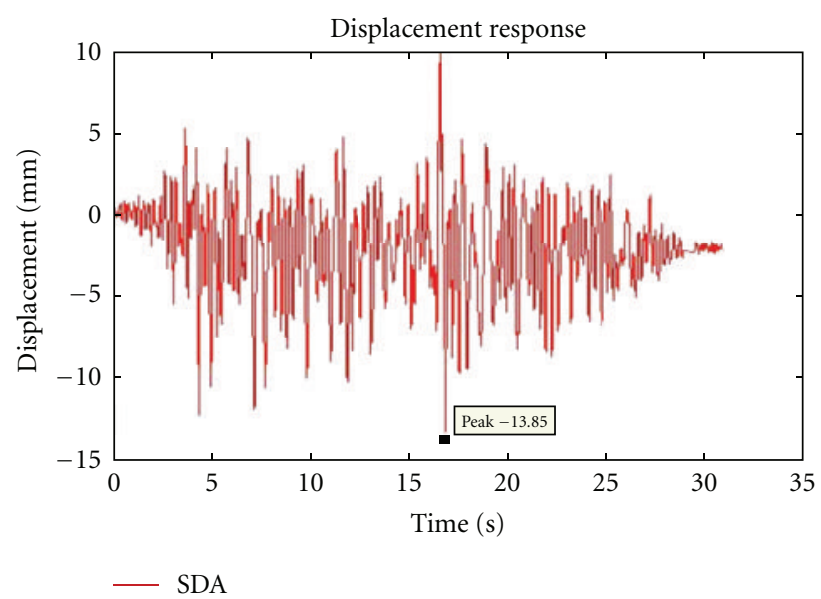

FIGURE 12: Displacement response of SDA concrete frame, column after test sequence 1 .

top of the column for the Portland cement and SDA concrete frames, respectively. Through the inspection of these figures, the one can see that the dynamic behavior is very similar for both the frame types.

By comparing the damage and peak displacement response values in Table 10, it can be seen that until test 2 both the SDA concrete frame and Portland cement concrete frame behaved in a similar manner with respect to their damage levels for the same ground motions, with the exception of the small shear crack. From test 3 to test 4 , it can be seen that the Portland cement concrete frame began to perform better than the SDA concrete frame from 
a displacement perspective although similar damage was observed in both the frames. After test 5, the SDA frame had suffered slightly more damage overall when compared to that of the concrete frame, but the difference was felt to be negligible considering the number and intensity of the ground motions used as input during the tests. Additionally, the SDA frame, even after being damaged in tests 3 and 4, had a slightly lower peak displacement in test 5 .

\section{Summary and Conclusions}

The objective of this study was to compare the experimental seismic performance of $1 / 3$ scale high SDA content concrete portal frames to conventional Portland cement concrete portal frames when subjected to the same series of earthquake ground motions. By comparing the damage levels and displacement response plots of the SDA frame to that of the Portland cement concrete frame after each earthquake, little difference was found in the response of the frames. It was only after test 3 that the SDA frame did not perform as well when compared to that of the Portland cement concrete frame. However, by the end of test 5 they had performed approximately equally. All three of these shakes were more intense than the current designbasis earthquake for the location these frames were designed. Development of shear cracks at the beam column joints in both Portland cement concrete frames and SDA concrete frames after a test sequence indicated that the frames behaved as per the designed strong column-weak beam concept. Regardless, there was no significant damage or structural failure, such as a collapse, exhibited by either frame. From a strictly structural standpoint, it can be stated that up to fifty percent of cement could be replaced with SDA in a concrete mix in place of ordinary Portland cement concrete for the construction of structural members in high seismic zones. This is underscored by the fact that the SDA mix was slightly weaker in compressive strength and still performed, in general, the same as the Portland cement frame. However, work in the area of durability and corrosion of reinforcement is needed prior to actual implementation of such a high SDA content into structural concrete. Clearly, if this can be studied and shown to be also viable from a ductility standpoint, then contents as high as 50\% SDA can be utilized thus reducing the cost of construction. Further, SDA can be recycled and diverted from landfills, thereby moving towards greener construction.

\section{References}

[1] Environmental Protection Agency (EPA), April 2010, http:// www.epa.gov .

[2] L. V. Heebink, "A review of literature related to the use of spray dryer absorber material. Production, characterization, utilization applications, barriers, and recommendations," Tech. Rep. 1014915, Electric Power Research Institute, 2007.

[3] C. E. Riley, High-volume use of self-cementing spray dry absorber material for structural applications, Ph.D. dissertation, Colorado State University, Fort Collins, Colo, USA, 2009.
[4] N. Swamy, A. Sami, R. Ali, and D. D. Theodorakopoulos, "Early strength fly ash concrete for structural applications," ACI Journal Proceedings, vol. 80, no. 5, pp. 414-423, 1983.

[5] R. C. Joshi, J. M. Oswell, and G. S. Natt, "Laboratory investigations on concrete and geocrete with high fly ash contents," in Proceedings of the International Ash Utilization Symposium and Exposition, vol. 2, 1985.

[6] S. E. Hussain and Rasheeduzzafar, "Corrosion-resistance performance of fly-ash blended cement concrete," ACI Materials Journal, vol. 91, no. 3, pp. 264-272, 1994.

[7] M. Pigeon and V. M. Malhotra, "Frost resistance of rollercompacted high-volume fly ash concrete," Journal of Materials in Civil Engineering, vol. 7, no. 4, pp. 208-211, 1995.

[8] J. M. Bracci, A. M. Reinhorn, and J. B. Mander, "Seismic resistance of reinforced concrete frame structures designed only for gravity loads-part I: design and properties of onethird scale model structure," Tech. Rep. NCEER -92-0027, 1992.

[9] G. Dinelli, G. Belz, C. E. Majorana, and B. A. Schrefler, "Experimental investigation on the use of fly ash for lightweight precast structural elements," Materials and Structures/Materiaux et Constructions, vol. 29, no. 194, pp. 632-638, 1996.

[10] A. Fernandez-Jimenez, I. García-Lodeiro, and A. Palomo, "Durability of alkali-activated fly ash cementitious materials," Journals of Material Science, vol. 42, no. 9, pp. 3055-3065, 2007.

[11] J. W. van de Lindt, J. A. H. Carraro, P. R. Heyliger, and C. Choi, "Application and feasibility of coal fly ash and scrap tire fiber as wood wall insulation supplements in residential buildings," Resources, Conservation and Recycling, vol. 52, no. 10, pp. 1235-1240, 2008.

[12] ASCE, Minimum Design Loads for Buildings and other Structures, American Society of Civil Engineering; Structural Engineering Institute, Reston, Va, USA, 2005.

[13] E. Buckingham, “The principle of similitude," Nature, vol. 96, no. 2406, pp. 396-397, 1915.

[14] ACI, Building Code Requirements for Structural Concrete, American concrete Institute 318-05, 2005.

[15] B. King, Making of Better Concrete, Guidelines to Using Fly Ash for High Quality Eco-Friendly Structures, Green Building Press, 2005. 

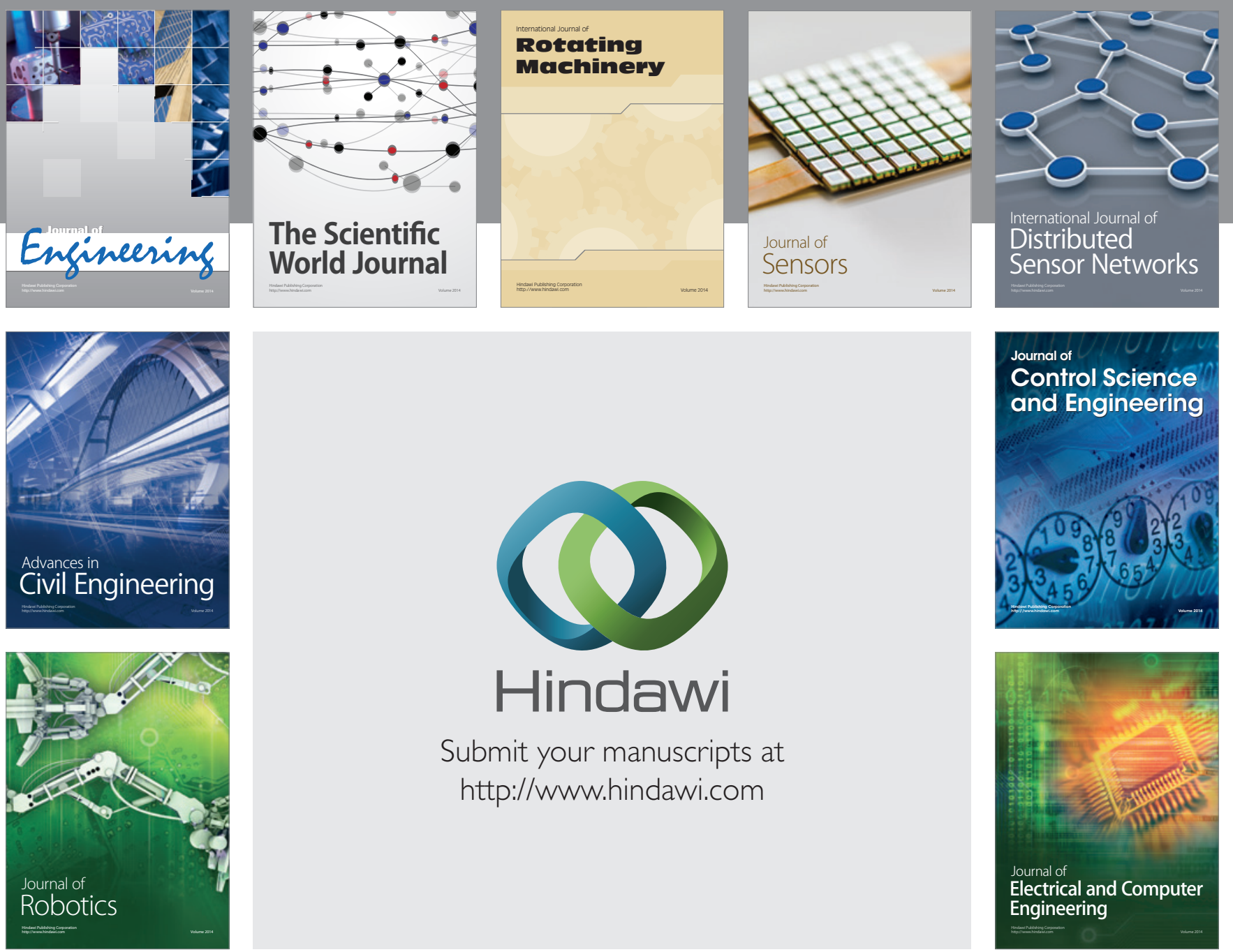

Submit your manuscripts at

http://www.hindawi.com
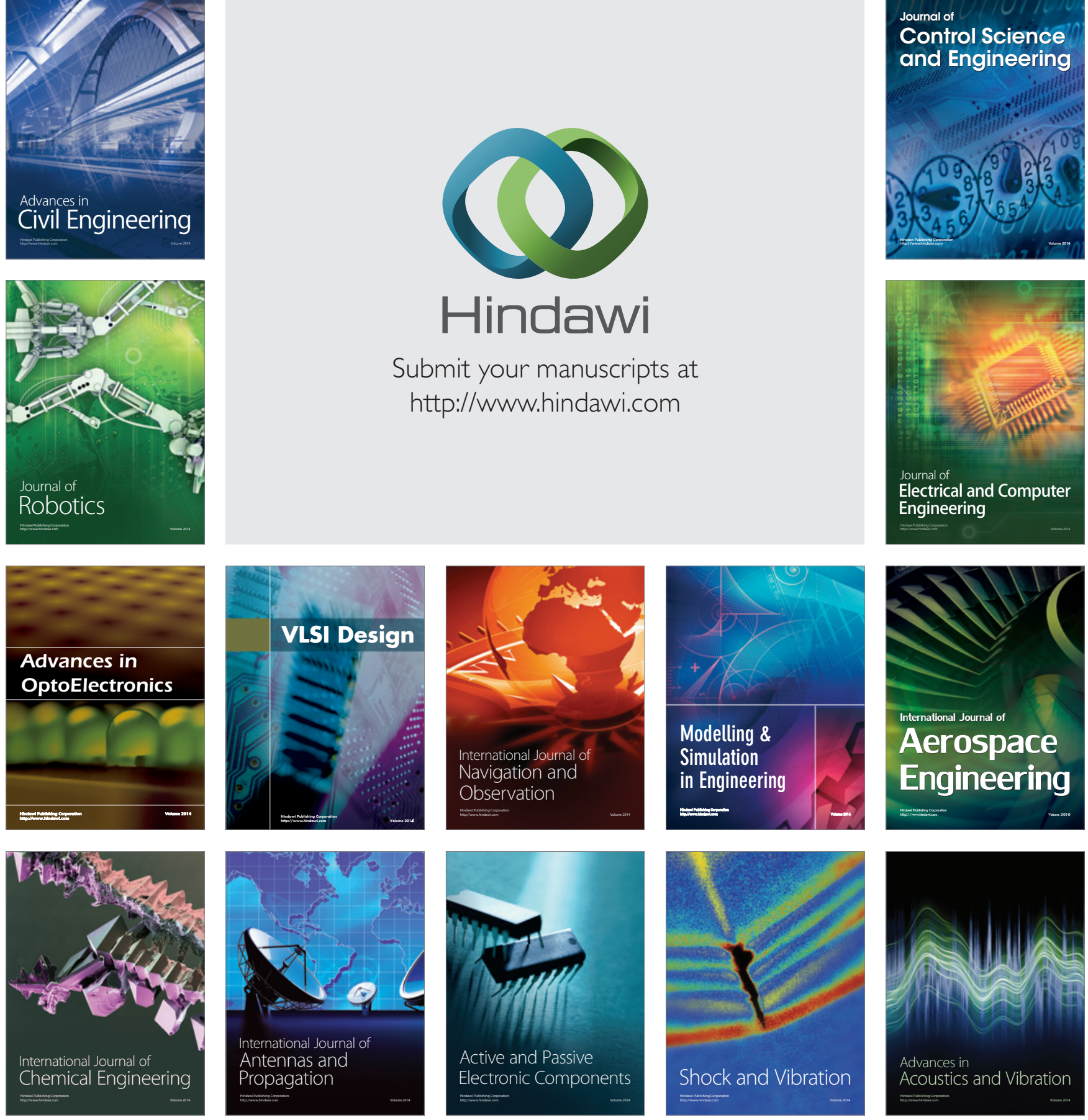